\title{
Analisis Dinamika Populasi Ternak Sapi di Provinsi Jambi
}

\section{Analysis of Cattle Population Dynamics in Jambi Province}

\author{
Nursholeh $^{\text {1) }}$, Firmansyah ${ }^{2)}$ dan Fachroerrozi Hoesni2) \\ ${ }^{1)}$ Alumni Magister Ilmu Peternakan Pascasarjana Universitas Jambi \\ Email:nursholehnote8@gmail.com \\ ${ }^{2)}$ Magister Ilmu Peternakan Pascasarjana Universitas Jambi \\ Kampus Telanaipura Jl. Arif Rahman Hakim, Telanaipura, Kec. Telanaipura, \\ Kota Jambi, Jambi 36361
}

\begin{abstract}
Diterima $\quad: 14$ Februari 2020
Disetujui : 29 Februari 2020

Diterbitkan : 29 Februari 2020
\end{abstract}

\begin{abstract}
Abstrak: Jumlah populasi ternak sapi di Provinsi Jambi selama dua dekade lebih mengalami naik turun, meskipun menunjukkan adanya tren kenaikan. Tidak stabilnya populasi sapi di Provinsi Jambi disebabkan pertumbuhan dinamika populasi yang selalu turun naik setiap tahun. Penelitian ini bertujuan untuk mengetahui dinamika pertumbuhan gross dan net populasi ternak sapi di Provinsi Jambi dan perbedaan antara kabupaten/kota di Provinsi Jambi, serta faktor yang mempengaruhinya. Penelitian ini menggunakan metode analisis data sekunder dalam bentuk data tahunan/berkala (time series). Analisis data yang digunakan adalah analisis trend dan analisis uji beda serta analisis regresi linear berganda. Hasil analisis trend menunjukkan bahwa ada trend peningkatan gross populasi ternak sapi sebesar 2,96\% per tahun dan net populasi sebesar 3,70 \% per tahun selama periode 2010-2017. Hasil uji beda (significant $=\leq \alpha=0,05$ ) menunjukkan bahwa tidak terdapat perbedaan gross dan net populasi ternak sapi pada kelompok populasi banyak, sedang dan sedikit antara kabupaten/kota di Provinsi Jambi. Tidak terdapat pengaruh kelahiran ( $\left.X_{1}\right)$, pemasukan $\left(X_{2}\right)$ terhadap gross populasi ternak sapi di Provinsi Jambi. Tidak terdapat pengaruh pengeluaran $\left(X_{1}\right)$, pemotongan $\left(X_{2}\right)$, dan kematian $\left(X_{3}\right)$ terhadap net populasi ternak sapi di Provinsi Jambi.
\end{abstract}

Kata Kunci: dinamika populasi, ternak sapi

Abstract: The number of cattle population in Jambi Province over two decades has fluctuated, although it shows an upward trend. The unstable population of cattle in Jambi Province is due to population dynamics that always fluctuate every year. This study aims to determine the dynamics of gross and net population growth of cattle in Jambi Province and the differences between districts / cities in Jambi Province, as well as the factors that influence it. This study uses secondary data analysis methods in the form of annual / periodical data (time series). Analysis of the data used is trend analysis and analysis of different tests and multiple linear regression analysis. The result of trend analysis shows that there is a trend of an increase in the gross population of cattle by $2.96 \%$ per year and a net population of $3.70 \%$ per year during the 2010-2017 period. Different test results (significant $=\leq \alpha=0.05$ ) show that there is no difference in gross and net population of cattle in large, medium and small population groups between districts / cities in Jambi Province. There is no effect of birth ( $\left.\mathrm{X}_{1}\right)$, income $\left(\mathrm{X}_{2}\right)$ on the gross population of cattle in Jambi Province. There is no influence of expenditure $\left(X_{1}\right)$, slaughter $\left(X_{2}\right)$, and death $\left(X_{3}\right)$ on the net population of cattle in Jambi Province.

Keywords: population dynamics, cattle

\section{Pendahuluan}

Kebutuhan (demand) daging selalu lebih tinggi dari produksi (supply) yang tersedia, sehingga ketergantungan ternak sapi dari luar semakin meningkat. Selama sepuluh tahun terakhir permintaan konsumsi daging sapi terus meningkat dan telah melebihi kemampuan produksi daging sapi dalam negeri. Berdasarkan data Badan Pusat Statistik Indonesia selama periode 2009-2018, populasi sapi dalam negeri berfluktuasi, meskipun menunjukkan adanya trend kenaikan. Konsumsi dalam negeri juga mengalami kenaikan setiap tahunnya dengan laju peningkatan konsumsi daging sapi yang mencapai 4,66\%. Jika dibandingkan dengan laju peningkatan produksi sapi jauh lebih rendah (3,20\%). Akibatnya dalam jangka panjang akan menyebabkan terjadinya kelebihan permintaan [1]. Upaya yang dilakukan untuk memenuhi kelebihan permintaan daging sapi adalah dengan impor. Jumlah populasi ternak sapi di Provinsi Jambi selama dua dekade lebih mengalami 
naik turun, meskipun menunjukkan adanya trend kenaikan. Hal ini dapat dilihat data populasi ternak sapi sebanyak 151.108 ekor tahun 1997 menjadi 159.546 ekor tahun 2017 dengan rata-rata tumbuh 1,13\% per tahun. Berdasarkan data yang dikeluarkan oleh Badan Pusat Statistik Indonesia, pertumbuhan populasi sapi di Provinsi Jambi lebih rendah dibandingkan dengan populasi sapi nasional pertumbuhan populasi sapi nasional selama sepuluh tahun terakhir yang ratarata pertumbuhannya sebesar $3,75 \%$ per tahun.

Tidak stabilnya populasi sapi di Provinsi Jambi disebabkan pertumbuhan dinamika populasi yang selalu turun naik setiap tahun. Dinamika populasi ternak sapi di Provinsi Jambi terdiri dari jumlah populasi ternak sapi, produksi ternak sapi, pemotongan ternak sapi, pengeluaran ternak sapi dari Provinsi Jambi, pemasukan ternak sapi ke dalam Provinsi Jambi, kelahiran ternak sapi, serta kematian ternak sapi. Dinamika populasi sapi suatu wilayah dipengaruhi oleh kelahiran ternak sapi, kematian ternak sapi, mutasi ternak sapi dan pemotongan ternak sapi [2]. Dinamika populasi ternak sapi dihitung berdasarkan data populasi ternak sapi beberapa tahun terakhir [3]. Berdasarkan uraian di atas maka dilaksanakan penelitian dengan judul "Analisis Dinamika Populasi Ternak Sapi di Provinsi Jambi".

\section{Materi dan Metode}

\subsection{Metode Pengumpulan Data}

Metode penelitian yang digunakan dalam penelitian ini adalah dengan menggunakan analisis data sekunder. Data yang digunakan dalam penelitian ini adalah data sekunder yang disajikan dalam bentuk data tahunan/berkala (time series). Jenis data yang digunakan meliputi data populasi ternak sapi, kelahiran ternak sapi, pemasukan ternak sapi, pengeluaran ternak sapi, pemotongan ternak sapi dan kematian ternak sapi selama periode 2010-2017 di kabupaten/kota dan Provinsi Jambi.

\subsection{Analisis Data}

Analisis yang digunakan untuk mengetahui pertumbuhan gross populasi dan pertumbuhan net populasi ternak sapi di Provinsi Jambi adalah analisis trend. Trend adalah suatu gerakan (kecenderungan) naik atau turun dalam jangka panjang, yang diperoleh dari rata-rata perubahan dari waktu ke waktu [4]. Berikut rumus yang digunakan untuk menghitung gross populasi dan net populasi :

1. Gross populasi $=$ jumlah populasi ternak sapi + kelahiran ternak ternak sapi + pemasukan ternak sapi

2. Net populasi $=$ gross $-($ Pengeluran ternak sapi + pemotongan ternak sapi + kematian ternak sapi).

Perbedaan dinamika pertumbuhan gross populasi dan pertumbuhan net populasi ternak sapi antara Kabupaten/kota di Provinsi Jambi diuji menggunakan uji beda (Uji-T) [5]. Analisis regresi linear berganda digunakan untuk mengetahui pengaruh faktor jumlah populasi ternak sapi tahun lalu, jumlah kelahiran ternak sapi dan jumlah pemasukan ternak sapi terhadap dinamika pertumbuhan gross populasi, serta faktor jumlah pengeluaran ternak sapi, jumlah kematian ternak sapi dan jumlah pemotongan ternak sapi terhadap dinamika pertumbuhan net populasi ternak sapi di Provisi Jambi [6].

\section{Hasil dan Pembahasan}

\subsection{Pertumbuhan Gross Populasi Ternak Sapi di Provinsi Jambi}

Gross populasi ternak sapi adalah penjumlahan antara populasi ternak sapi yang ada dengan kelahiran ternak sapi dan pemasukan ternak sapi dalam periode yang sama[7]. Pertumbuhan gross populasi ternak sapi di Provinsi Jambi selama periode 8 tahun terakhir mengalami fluktuasi dengan kecenderungan meningkat. Secara rata-rata gross populasi ternak sapi di Provinsi Jambi selama periode tahun 2010-2017 tumbuh sebesar 2,96\% per tahun. Pertumbuhan gross populasi ternak sapi di Provinsi Jambi tertinggi pada tahun 2011 sebesar 14,10 \% atau sebanyak 269.316 ekor dibanding gross populasi ternak sapi pada tahun 2010 (236.035 ekor).

Penurunan gross populasi ternak sapi di Provinsi Jambi terjadi selama 3 tahun berturut-turut mulai dari 2012-2014. Penurunan gross populasi ternak sapi tertinggi pada tahun 2014 yaitu sebesar -0,75\% menjadi 262.501 ekor, turun dibanding pada tahun 2013 sebanyak 266.499 ekor. Perkembangan gross populasi ternak sapi di Provinsi Jambi tersaji pada Grafik 1. 


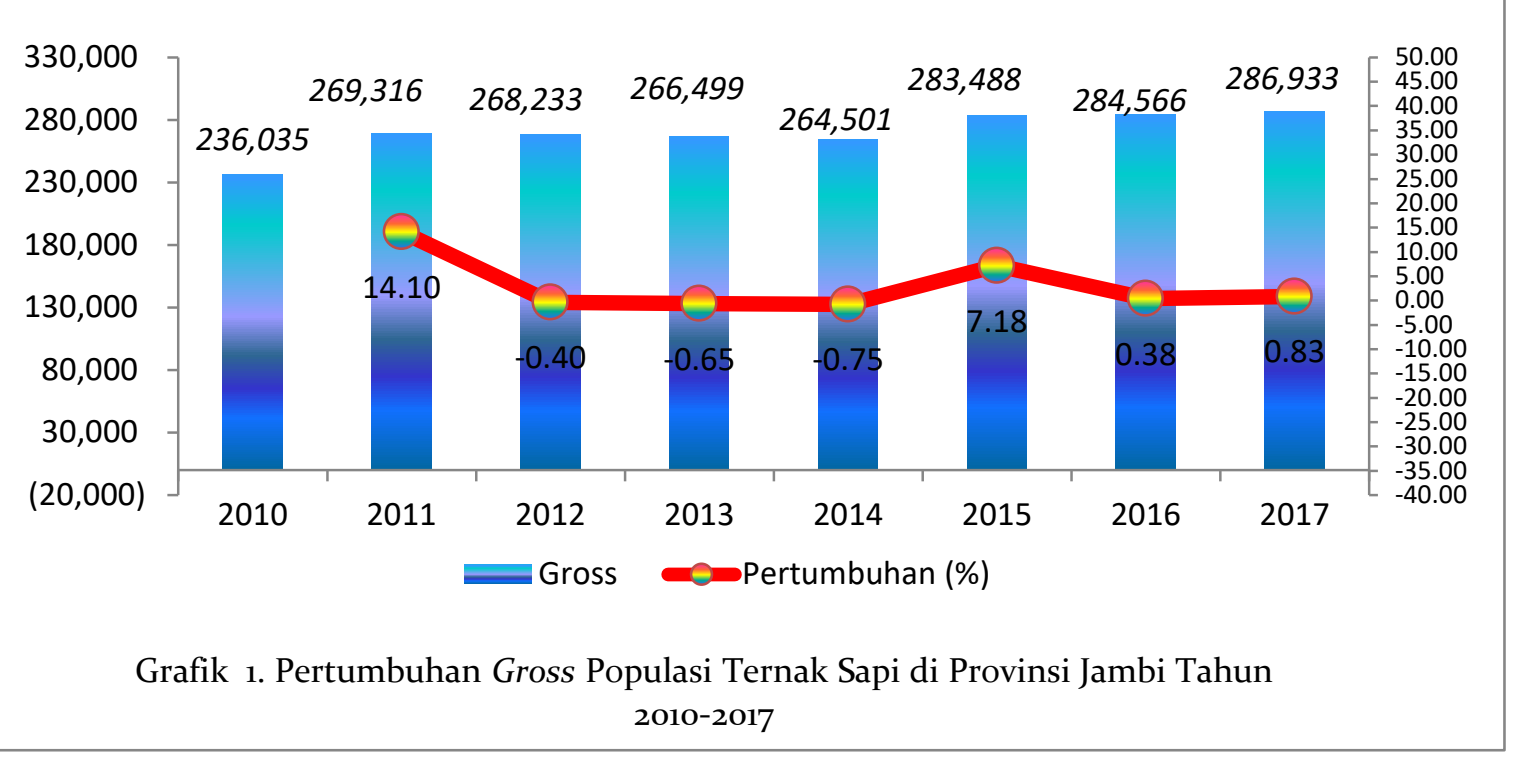

Faktor-faktor yang mempengaruhi fluktuasi gross ternak sapi di Provinsi Jambi adalah jumlah kelahiran ternak sapi di Provinsi Jambi dan pemasukan ternak sapi ke Provinsi Jambi. Gross populasi adalah penjumlahan antara populasi yang ada dengan kelahiran dan pemasukan ternak dalam periode yang sama, angka kelahiran dan pemasukan ternak inilah yang membentuk Gross populasi. Dikatakan gross populasi karena belum dilakukan pengurangan atau koreksi terhadap jumlah penjualan, pemotongan, dan kasus kematian ternak [8].

\subsection{Pertumbuhan Net Populasi Ternak Sapi di Provinsi Jambi}

Net populasi adalah hasil pengurangan gross populasi dengan jumlah ternak yang keluar daerah (penjualan), dipotong, dan yang terkena kasus kematian [1]. Net populasi ternak sapi di Provinsi Jambi periode 2010-2017 tidak stabil dengan cenderung meningkat. Populasi pada tahun 2010 sebanyak 177.710 ekor meningkat sebanyak 225.563 ekor pada tahun 2017 atau rata-rata net populasi ternak sapi meningkat sebesar 3,70 \% per tahun. Net populasi ternak sapi selama periode (2010-201) di Provinsi Jambi tersaji pada Grafik 2.

Faktor yang mempengaruhi net populasi ternak sapi di Provinsi Jambi adalah jumlah pengeluaran ternak, jumlah pemotongan ternak dan jumlah kematian ternak setiap tahunnya. Net populasi adalah hasil pengurangan gross populasi dengan jumlah pengeluaran ternak, pemotongan, dan terkena kasus kematian. Dikatakan net populasi karena secara aktual jumlah ini hidup dan dibudidayakan oleh peternak untuk kepentingan produksi yang lebih lanjut. Dengan kata lain bahwa net populasi adalah penjumlahan dari populasi aktual ditambah jumlah kelahiran dan pemasukan dikurangi dengan jumlah penjualan, pemotongan, dan kasus kematian [8].

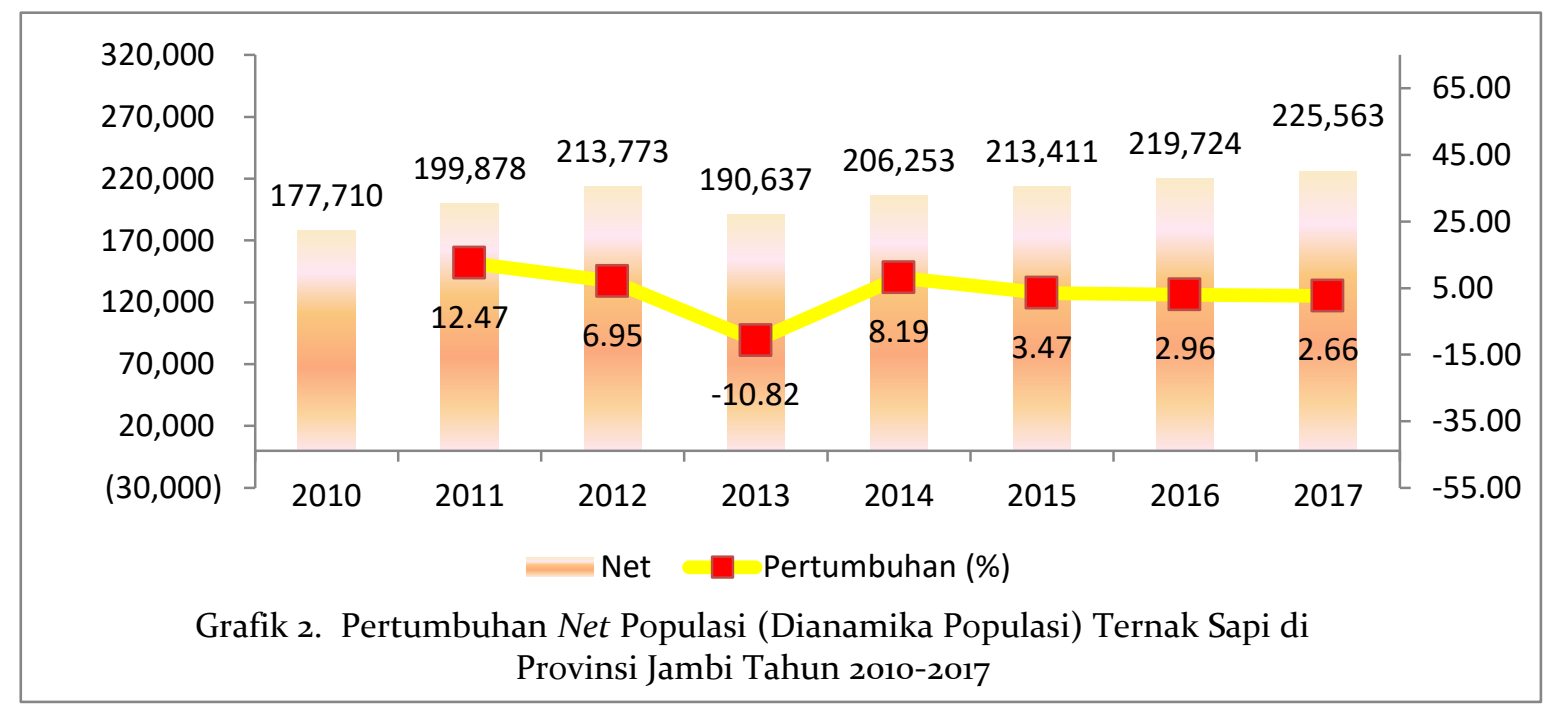


Penurunan populasi ternak disebabkan oleh beberapa faktor, antara lain rendahnya tingkat kelahiran, tingginya pemotongan dan tingkat kematian serta pengembangan lingkungan hidup ternak yang semakin terdesak akibat kurangnya padang pengembalaan [9].

\section{Analisis uji beda pertumbuhan gross ternak sapi}

Analisis uji beda (Uji-T) digunakan untuk melihat bagaimana perbedaan pertumbuhan gross populasi ternak sapi antara kabupaten/kota di Provinsi Jambi pada jumlah populasi banyak (>30.ooo ekor), jumlah populasi sedang (20.00o - 30.000 ekor) dan jumlah populasi sedikit (<20.00o ekor). Analisis uji beda (significan $=\leq \alpha=0,05$ ), menunjukkan bahwa pertumbuhan gross populasi ternak sapi di Provinsi Jambi selama periode 8 tahun terakhir (20102017) untuk kelompok kabupaten/kota yang memiliki jumlah populasi banyak (>30.0oo ekor) pada Kabupaten Bungo tidak berbeda dengan Kabupaten Muaro Jambi dan Kabupaten Kerinci. Selanjutnya tidak terdapat perbedaan antara Kabupaten Muaro Jambi dengan Kabupaten Kerinci.

Analisis uji beda (signifikansi $\leq \alpha=0,05$ ), menunjukkan bahwa pertumbuhan gross populasi ternak sapi di Provinsi Jambi selama periode 8 tahun terakhir dimulai dari tahun 2010-2017 untuk kelompok kabupaten/kota yang memiliki jumlah populasi sedang (20.00o - 30.000 ekor) pada Kabupaten Merangin tidak berbeda dengan Kabupaten Tanjung Jabung Timur.

Analisis uji beda (signifikansi $\leq \alpha=0,05$ ), menunjukkan bahwa pertumbuhan gross populasi ternak sapi di Provinsi Jambi selama periode (20102017) untuk kelompok kabupaten/kota yang memiliki jumlah populasi sedikit $(<20.000$ ekor) pada Kabupaten Tebo tidak berbeda dengan Kabupaten Tanjung Jabung Barat, Kabupaten Sarolangun, Kabupaten Batanghari, Kota Sungai Penuh dan Kota
Jambi. Selanjutnya tidak terdapat perbedaan pada Kabupaten Tanjung Jabung Barat dengan Kabupaten Sarolangun, Kabupaten Batanghari, Kota Sungai Penuh dan Kota Jambi. Berikutnya tidak terdapat perbedaan pada Kabupaten Sarolangun dengan Kabupaten Batanghari, Kota Sungai Penuh dan Kota Jambi. Kemudian tidak terdapat perbedaan pada Kabupaten Batanghari dengan Kota Sungai Penuh dan Kota Jambi. Tidak terdapat perbedaan antara Kota Sungai Penuh dengan Kota Jambi.

Faktor yang mempengaruhi gross populasi ternak sapi di Provinsi Jambi

Hasil analisis model summary pada pengaruh kelahiran ternak sapi $\left(\mathrm{X}_{1}\right)$ pemasukan ternak sapi (X2) terhadap gross ternak sapi di Provinsi Jambi (Y) menghasilkan koefisien determinansi $\mathrm{R}_{2}$ sebesar o,09o. Untuk melakukan uji F, maka pasangan hipotesis dirumuskan adalah : Ho : $\mathrm{PYX}_{1}=\mathrm{PYX}_{2}=\mathrm{o}$ dan $\mathrm{H}_{1}$ sekurang-kurangnya ada sebuah PYX ila o. Hasil analisis uji $\mathrm{F}$ diperoleh nilai Fhitung $=0,246 \leq$ Ftabel $=5.14$ dengan signifikansi $0,791 \geq 0,05$ yang berarti hipotesis nol diterima dan hipotesis alternatif ditolak, artinya tidak terdapat satu nilai variabel yang berarti (signifikan). Hasil ini menunjukkan bahwa pengaruh kelahiran ternak sapi $\left(\mathrm{X}_{1}\right)$, pemasukan ternak sapi $\left(\mathrm{X}_{2}\right)$ tidak mempengaruhi gross populasi ternak sapi di Provinsi Jambi.

Berdasarkan uji $\mathrm{t}$ diperoleh hasil untuk variabel kelahiran ternak sapi $\left(\mathrm{X}_{1}\right)$, pemasukan ternak sapi (X2) ternyata tidak ada variabel yang signifikan yaitu variabel untuk kelahiran ternak sapi (Xı) signifikansi $0,565>0,05$ sedangkan untuk variabel pemasukan ternak sapi (X2) signifikansi o,693 < 0,05. Hasil analisis uji beda menunjukkan bahwa tidak terdapat pengaruh secara bersamaan antara faktor kelahiran ternak sapi dan pemasukan ternak sapi terhadap dinamika pertumbuhan gross populasi ternak sapi di Provinsi Jambi selama periode 2010-2017.

Tabel 1. Analisis uji beda pertumbuhan gross populasi ternak sapi antara kabupaten/kota yang memiliki jumlah populasi banyak, sedang dan sedikit di Provinsi Jambi

\begin{tabular}{|c|c|c|c|c|}
\hline Kelompok Populasi & Kabupaten/kota & Rata-rata (ekor) & Sig. (2-tailed) & Uji Beda \\
\hline \multirow{6}{*}{ Banyak (>30.0oo ekor) } & Bungo & $2.427 \pm 3.284$ & \multirow{2}{*}{0,151} & \multirow{2}{*}{ Tidak signifikan } \\
\hline & Muaro Jambi & $6.991 \pm 7.164$ & & \\
\hline & Bungo & $2.427 \pm 3.284$ & \multirow{2}{*}{0,531} & \multirow{2}{*}{ Tidak signifikan } \\
\hline & Kerinci & $9.060 \pm 26.992$ & & \\
\hline & Muaro Jambi & $6.991 \pm 7.164$ & \multirow{2}{*}{0,848} & \multirow{2}{*}{ Tidak signifikan } \\
\hline & Kerinci & $9.060 \pm 26.992$ & & \\
\hline \multirow{2}{*}{$\begin{array}{c}\text { Sedang } \\
(20.000-\text { 3o.ooo ekor }) \\
\end{array}$} & Merangi & $2.042 \pm 7.100$ & \multirow{2}{*}{0,266} & \multirow{2}{*}{ Tidak signifikan } \\
\hline & Tanjabtim & $7.944 \pm 11.329$ & & \\
\hline \multirow{5}{*}{ Sedikit $(<20.000$ ekor $)$} & Tebo & $-1.351 \pm 11.771$ & \multirow{2}{*}{0,650} & \multirow{2}{*}{ Tidak signifikan } \\
\hline & Tanjabbar & $1.705 \pm 12.787$ & & \\
\hline & Tebo & $-1.351 \pm 11.771$ & \multirow{2}{*}{0,366} & \multirow{2}{*}{ Tidak signifikan } \\
\hline & Sarolangun & $3.3472 \pm 6.069$ & & \\
\hline & Tebo & $-1.351 \pm 11.771$ & 0,543 & Tidak signifikan \\
\hline
\end{tabular}




\begin{tabular}{|c|c|c|c|c|}
\hline Kelompok Populasi & Kabupaten/kota & Rata-rata (ekor) & Sig. (2-tailed) & Uji Beda \\
\hline & Batanghari & $13 \cdot 377 \pm 61.133$ & & \\
\hline & Tebo & $-1.351 \pm 11.771$ & \multirow{2}{*}{0,299} & \multirow{2}{*}{ Tidak signifikan } \\
\hline & Sungai Penuh & $3.675 \pm 3.358$ & & \\
\hline & Tebo & $-1.351 \pm 11.771$ & \multirow{2}{*}{0,869} & \multirow{2}{*}{ Tidak signifikan } \\
\hline & Jambi & $0.075 \pm 19.019$ & & \\
\hline & Tanjabbar & $1.705 \pm 12.787$ & \multirow{2}{*}{0,848} & \multirow{2}{*}{ Tidak signifikan } \\
\hline & Sarolangun & $3.3472 \pm 6.069$ & & \\
\hline & Tanjabbar & $1.705 \pm 12.787$ & \multirow{2}{*}{0,630} & \multirow{2}{*}{ Tidak signifikan } \\
\hline & Batanghari & $13.377 \pm 61.133$ & & \\
\hline & Tanjabbar & $1.705 \pm 12.787$ & \multirow{2}{*}{0,700} & \multirow{2}{*}{ Tidak signifikan } \\
\hline & Sungai Penuh & $3.675 \pm 3.358$ & & \\
\hline & Tanjabbar & $1.705 \pm 12.787$ & \multirow{2}{*}{0,854} & \multirow{2}{*}{ Tidak signifikan } \\
\hline & Jambi & $0.075 \pm 19.019$ & & \\
\hline & Sarolangun & $3.3472 \pm 6.069$ & \multirow{2}{*}{0,673} & \multirow{2}{*}{ Tidak signifikan } \\
\hline & Batanghari & $13 \cdot 377 \pm 61.133$ & & \\
\hline & Sarolangun & $3.3472 \pm 6.069$ & \multirow{2}{*}{0,902} & \multirow{2}{*}{ Tidak signifikan } \\
\hline & Sungai Penuh & $3.675 \pm 3.358$ & & \\
\hline & Sarolangun & $3.3472 \pm 6.069$ & \multirow{2}{*}{0,672} & \multirow{2}{*}{ Tidak signifikan } \\
\hline & Kota Jambi & $0.075 \pm 19.019$ & & \\
\hline & Batanghari & $13.377 \pm 61.133$ & \multirow{2}{*}{0,682} & \multirow{2}{*}{ Tidak signifikan } \\
\hline & Sungai Penuh & $3.675 \pm 3.358$ & & \\
\hline & Batanghari & $13.377 \pm 61.133$ & \multirow{2}{*}{0,593} & \multirow{2}{*}{ Tidak signifikan } \\
\hline & Jambi & $0.075 \pm 19.019$ & & \\
\hline & Sungai Penuh & $3.675 \pm 3.358$ & \multirow{2}{*}{0,631} & \multirow{2}{*}{ Tidak signifikan } \\
\hline & Kota Jambi & $0.075 \pm 19.019$ & & \\
\hline
\end{tabular}

\section{Kesimpulan}

Berdasarkan hasil penelitian ini dapat disimpulkan ada trend peningkatan setiap tahun untuk pertumbuhan gross populasi dan net populasi ternak sapi di Provinsi Jambi. Tidak ada perbedaan pertumbuhan gross populasi ternak sapi dan net populasi ternak sapi antara kabupaten/kota di Provinsi Jambi. Tidak terdapat pengaruh faktor kelahiran ternak sapi dan pemasukan ternak sapi terhadap dinamika pertumbuhan Gross populasi serta tidak terdapat pengaruh faktor pengeluaran ternak sapi, pemotongan ternak sapi dan kematian ternak sapi terhadap dinamika pertumbuhan Net populasi ternak sapi di Provinsi Jambi.

\section{Referensi}

[1] Harmini, Asmarantaka, R.W., dan Atmakusuma, Y. 2011. Model Dinamis Sistem Ketersediaan Daging Sapi Nasional. Jurnal Ekonomi Pembangunan. 12(1) : 130-148.

[2] Sumadi, A. Fathoni, S. B. Kusuma dan D. N. H. Haryono. 2016. : Estimasi Output dan Dinamika Populasi Sapi Potong Di Kabupaten Klaten, Jawa Tengah. Fakultas Peternakan.

[3] Kusuma B. Satria, N. Ngadiyono dan Sumadi. 2017. Estimasi Dinamika Populasi dan Penampilan Reproduksi Sapi Peranakan Ongole di Kabupaten Kebumen Provinsi Jawa Tengah. Buletin Peternakan Vol. 41 (3) Hal 230-242.

[4] Maryati, 2010. Statistika Ekonomi dan Bisnis, Edisi Revisi Cetakan Kedua Yogyakarta (UPP) AMPYKPN

[5] Sarwono, J. 2007. Analisis Jalur untuk Riset Bisnis dengan SPSS. Yogyakarta: Penerbit Andi

[6] Suharyadi \& Purwanto. 2004. Metodologi Penelitian.Jakarta: Gramedia Pustaka Utama.

[7] Ditjennak. 2013. Blue Print Program Swasembada Daging Sapi. Ditjennak. Kementerian Pertanian. Jakarta.

[8] Paly, B. 2013. Pertumbuhan Gross dan Net Populasi Ternak Sapi di Sulawesi Selatan. Biogenesis. Jurnal Ilmiah Biologi. Vol 1, No. 1, Juni 2013, hal 33-40.

[9] Ilham, N. 1995. Strategi Pengembangan Ternak Ruminansia di Indoesia Ditinjau dari Potensi Sumbedaya Pakan dan Lahan. 